\title{
Certification of nagari assets in west sumatra
}

\author{
Yontri Faisal ${ }^{*}$ and Muhammad Yamin Lubis
}

Law Program, University of Sumatera Utara, Jl. Abdul Hakim No. 4, Medan, 20155, North Sumatera, Indonesia

\begin{abstract}
Nagari in West Sumatra is the same as "customary village" (Article 7 of Act Number 6 of 2014 concerning the Village) which is the spearhead of the lowest administrative region. Nagari as the lowest government also has an assets, both in the form of land and others form. The legal certainty of the Nagari asset in the form of land is held through land certification. In general, Nagari assets are communal lands. with the empowerment of Nagari assets in West Sumatera, through the Regional Government Budget and Expenditure, will provide wider space for the Nagari in utilizing its assets, in an effort to improve the Nagari economy, or at the same time to provide legal certainty regarding land assets. This research use theory of legal certainty. The conclusion of this research, concerning the certainty of certification of Nagari assets in the form of communal land has not provided legal certainty, because communal land does not include land certification object.
\end{abstract}

Keywords: Legal Certainty, Certification of Communal Land, Nagari Asset.

\section{Introduction}

Based on the West Sumatera Regional Regulation Number 9 of 2000 concerning the Basic Provisions of the Nagari Government that have been replaced by Regional Regulation Number 2 of 2007 concerning the Principles of Nagari Government. This regulation as an application of Act Number. 22 of 1999 concerning Regional Government which has also been replaced by Act Number 32 of 2004, then Act Number 23 of 2014, then changed with Government Regulation in Liew of Legislation Act Number 2 of 2014 , and last changed with Act Number 9 of 2015 concerning Regional Government.

Fresh Winds concerning the Government of Nagari, since the issuance of Act Number 6 of 2014 concerning the Village which then followed up with some provisions of implementers such as Government Regulation Number 43 of 2014 concerning the Implementation of Act Number 6 of 2014 concerning the Village, which then changed with Government Regulation Number 47 of 2015 concerning the amendment of Government Regulation Number 43 of 2014 concerning the implementation of Act Number 6 of 2014 and Regulation of the Minister of Home Affairs of the Republic of Indonesia Number 83 of 2015 concerning Appointment and Dismissal of Village Devices. then Regulation of the

*Corresponding Author:yontrifaisal3@gmail.com

(C) The Authors, published by EDP Sciences. This is an open access article distributed under the terms of the Creative Commons Attribution License 4.0 (http://creativecommons.org/licenses/by/4.0/). 
Minister of Home Affairs of the Republic of Indonesia Number 1 of 2016 concerning Utilization of Village Assets.

The total area of West Sumatra Province is $42,200 \mathrm{~km}^{2}$ or equal to $2.21 \%$ of the total area of Indonesia consisting of 19 second level regions, 648 nagari. Nagari administration in West Sumatra has been known for a long time, with the governance system of Koto Piliang and Bodi Caniago. The formation of Nagari was once determined to be at least four tribes (Nagari Baampek Tribe), with the territory determined first. Thus the existence of nagari and communal system is inherent in Minangkabau culture. ${ }^{[1]}$

There are 4 Functions of Nagari Government that need to be integrated into Regional Regulation Number 2 of 2007 that is:

1. Nagari as the lowest government unit of Indonesia is equivalent to the Village

2. Nagari as a unit of unitary custom and socio-cultural unity in order to embody the cultural philosophyAdat Basandi Syarak and Syarak Basandi Kitabullah (Custom Based on Sharia, Sharia Based on Kitabullah).

3. Nagari as a unit of communal land as a Nagari asset and as a unit of economic based economic entity.Nagari is a legal entity. Nagari can also try in the form of Nagari-owned enterprises or cooperative with the principles of sharia, in addition to the efforts of each villagers

4. Nagari as a unit of security and security units that autonomously can safeguard and protect the people and the wealth of Nagari. The existence of Custom Density of Nagari in the Regional Regulation Number 9 of 2000, replaced by Custom Density and Sharia with the principle of Adat Basandi Syarak and Syarak Basandi Kitabullah (Custom Based on Sharia, Sharia Based on Kitabullah). The members of custom density an sharia consist of elements of TTS (Tungku nan Tigo Sajarangan, Tali nan Tigo Sapilin) that is ninik-mamak, Ulama and the scholars plus elements of women and youth.

Nagari assets in the form of land, generally are communal land (tanah ulayat), which consists of three levels of ulayat nagari, tribe and kaum. The ulayat nagari can not be transferred to its ownership. In relation to the ulayat nagari land that has been transferred to the Right of Exploitation from any party needs to be returned to Nagari. Because the Right of Exploitation also can not come from communal rights (Article 28 Agrarian Act).

In Article 1 Paragraph (1) of the Village Act, it is affirmed that the village and customary village or other so-called names, hereinafter referred to as the Village, is a legal community unit having the territorial boundaries to regulate and administer government affairs, the interest of the local community based on the initiative community, origin rights, and/or traditional rights recognized and respected within the system of government of the Unitary State of the Republic of Indonesia. In the paragraph (2) it is mentioned that the Village Government is the administration of the affairs of the government and the interests of the local people in the system of government of the Unitary State of the Republic of Indonesia or Integral Village with the government of the Republic of Indonesia.

Nagari asset management is a series of activities ranging from planning, procurement, utilization, security, maintenance, deletion, transfer, handling, reporting, assessment, guidance, supervision and control of village/Nagari assets. ${ }^{[2]}$ Management of Nagari's government assets have the same provisions with the management of government assets, both in Central Government, Provincial Government, Regency Government and City Government. 
In the case of assets in the form of land must be proven by the certificate to ensure legal certainty. ${ }^{[3]}$ The land in question is the surface of the earth, with some types of rights on it (Article 16 a Agrarian Act) ${ }^{[4]}$ which in its use includes also some of the earth's body beneath it and part of the space above it. ${ }^{[5]}$ The implementation of Nagari Government in relation to the land assets (Article 76 paragraph (1) of the Agrarian Act) states that the assets of the Village can be a Village cash, a communal land, ... etc, managed by the Village under the leadership of the Village Head, assisted by the Village Secretary and the asset management. ${ }^{[6]}$ Village assets/Nagari that are strategic one of them is communal land. ${ }^{[7]}$ Other village assets can also be derived from the property owned by the Government and the village-level Regional Government in the village may be granted ownership to the village (Article 76 paragraph (3), in Article 76 paragraph (4), (5) and (6) village's asset the form of village property which form of land must be certified on behalf of the Village Government. The Law concept of communal land certification in the provision of legal certainty concerning Nagari's assets, in the management and development of nagari is very necessary.

\section{Formulation of the Problem}

The problem of this research is formulated as: how Certification of Nagari asset interacts with customary land rights?

\section{Research Method}

This research is empirical juridical research. Research based on field data, ${ }^{[8]}$ besides that also use normative juridical method using secondary data from library. ${ }^{\left[{ }^{9]}\right.}$ Library data is collected from books, regulations and other documentation provided in the library, or private collection. ${ }^{[10]}$ Legal material collected through libraries includes primary legal materials, secondary legal materials, and tertiary legal materials, such as dictionaries, encyclopedias, legal magazines, etc. This study is descriptive, with data collection techniques through interviews with respondents who were determined purposively. The determination of the location of the research is also purposive, with the criteria of Minangkabau origin region, namely Luhak Nan Tou that is Tanah Datar, Luhak Tangah that is Agam Regency, and Luhak Nan Bungsu ie Lima Puluh Kota Regency. Then the Rantau area of Padang City. The nagari's identification is also done by purposive, Nagari Parahiyangan, Nagari Kapau in Luhak Agam, and Nagari Tarantang and Harau in Luhak Nan Bungsu, and the study uses a population that is a set of objects with the same characteristics, ${ }^{[11]}$ and in research is certification of nagari assets. ${ }^{[12]}$ The sample is a smaller part of a population.

\section{Literature Review}

Legal certainty as one of the objectives of law can be said as part of the effort to realize justice. The real form of legal certainty is the enforcement or enforcement of a law regardless of who does. With the legal certainty everyone can predict what will be experienced if a certain legal action. Certainty is necessary to realize the principle of equality before the law without discrimination. ${ }^{[13]}$

Certainty is a feature that can not be separated from the law, especially for written legal norms. The law without a certainty value will lose meaning because it can no longer be used as a behavioral guide for everyone. Certainty itself is referred to as one of the goals of the law. The word "certainty" is closely related to the principle of truth, which is something 
that can be strictly legalized. Through deductive logic, the rules of positive law are placed as major premises, whereas concrete events become minor premises. Through a closed logic system will immediately be obtained conclusion. The conclusion must be something that can be predicted, so everyone is obliged to hold on to it. It is with this grip that society becomes orderly. Therefore, certainty will lead people to the order. ${ }^{[14]}$

\section{Result and Discussion}

\subsection{Land Registration}

Objects of land registration are Right of Ownership, Right of Exploitation, Right of Building, Right of Use, Right of Management, Rights of Waqf, exclusively for state land not issued certificates, but communal land excluding land registration objects.This registration includes:

1. Measurement of land mapping and accounting;

2. Registration of land rights and transfers of those rights;

3. The provision of letters of proof of rights, which applies as a powerful evidentiary instrument. ${ }^{[15]}$

The certificate is a land title certificate. Registration is an appropriate tool to provide a description and identification of the soil which is the continous recording. ${ }^{[16]}$ The data in the Land Registration Office (LRO) are grouped into 2 (two) parts: ${ }^{[17]}$

1. Juridical Data Group, which collects data on the name of the right to the land, who the holder, the transfer and charging if any, all of these are collected in the Land Book.

2. Group of Physical Data that is collecting data about the location of the land where, the length/width of the soil and the boundaries of the land are all collected in the Measure Letter.

The implementation of land registration is done by the National Land Agency. Land registration is also done by adat principle principle that is done with clear, real and light. ${ }^{[18]}$ In the registration provisions, the registration object does not include communal land.

Regional assets/property is an important element in the framework of government administration and service to the community. ${ }^{[19]}$ For that, regional governments are required to manage regional wealth professionally, transparently, accountably, efficiently and effectively starting from the planning, distribution and utilization and supervision. ${ }^{[20]}$ For the management of fixed goods in the form of land there must be proof in the form of land certificate in accordance with the type of rights assigned to it.Government assets in the form of land must be certified on behalf of the Regional Government.

One of the difficulties in managing regional government assets is due to the status of the land, its use, the element of interest to the land. The land inventory of an administrated regional government comes from the Dutch government whose land can be bought, forcibly taken, and / or rented. Besides, there are also assets that are not easily traced evidence of ownership. ${ }^{[21]}$

Article 2 paragraph (4) of Agrarian Act affirms that the right to control the state can be authorized to regions and the communal peoples. Later in Government Regulation Number 40 of 1996, it is stipulated that for the government the right to use and the right of management shall be granted, with the right of management rights being the right of control as stipulated in Article 2 paragraph (4) and be given proof of their right in the form of a certificate.

Land procurement for the government may be used solely for its duties and functions but may also be granted to third parties if its rights are the right of management.Customary 
rights, although recognized in the Agrarian Act but do not have legal certainty, because it can not be certified with the existing provisions. Use rights and management rights for regional governments can not be granted on customary land, with respect to which communal land certification as a regional government asset requires in depth assessment.

\subsection{Relation Between Certification of Nagari Asset and the Communal Land Law}

Result of recapitulation at West Sumatera, it can be seen that the field of land that has been registered until 2015 only 672983 fields, with an area of 1055692.37 ha. The details of the types of rights are property rights, tenure, building use rights, use rights, management rights, property rights of apartment units, and Waqf land.

Of this amount is seen for private and public use rights of 5901 areas with an area of 292707.94 ha, and the right to manage a total of 55 areas with an area of 775.87 ha. This amount has not separated the regional government land that is licensed to use Rights of Use and Rights of Management. West Sumatra area of 42,297,30 $\mathrm{km}^{2}$, newly registered area of 1055692.37 ha, unknown how much communal land, and other land.

Land Procurement For the Land Needs of Local Goverment from communal land, most do not have any rights base, only once given by the community either with or without certificate, while national land agency also did not do the mapping of the certification. Over time, grandchildren appear materilinial and land use situation is quite significant, then certification of regional assets become constrained. There are also those who have been given a kind of compensation, but since there is no written proof, the child's nephew declared that the act never happened.

The procurement of land derived from communal lands is considered to be the same as other rights, often resulting in cospic contradictions, values and norms of the right to land for regional governments. The regional government's asset protection from communal land if not reused does not return to communal land, state land. Land certification of regional government asset, especially the nagari's asset which derived from communal land has not been well mapped in West Sumatera. Recapitulation of land registration in West Sumatra, but not visible communal land, but in fact most of the land is communal. From the list of land in West Sumatra seen a number of 672983 with an area of 1055,692.37 ha, no detailed of communal land.

In the Agrarian Act, expressly recognized customary rights (ulayat rights) (Article 3 Agrarian Act), whereas public legal entities are only possible acquisition of their rights from state lands, not from communal Land. With the Village Act, the nagari administration can propose the certification land to be assigned to its duties and functions with a request for rights. Certification of nagari assets in the form of ulayat right with Government Regulation Number 24 of 1997, destroyed the concept of customary rights themselves. If the implementation of the nagari government lies on customary land of society, the nagari may be facilitated by liberation and/or by grant. Likewise, the nagari administration needs land which has been certificated with individual rights, it can be done by the acquisition of land (Act Number 2 of 2012). ${ }^{[22]}$ Nagari's assets/property is one of the important elements in the administration of government and services to the people in the nagari, therefore Nagari government is required to manage the Nagari wealth professionally, transparently, accountably, efficiently and effectively starting from planning, distribution and utilization and its supervision. ${ }^{[23]}$

With regard to legal certainty Nagari's assets in the form of land must be certified according to Article 19 of the Agrarian Act. through Government Regulation number 24 of 1997 concerning land registration. The certificate is a proof of legal certainty of Nagari land rights. According to Government Regulation Number 24 of 1997, the types of land rights 
that are required to be registered are listed, but excluding communal land under Article 3 of the Agrarian Act. Registration is an appropriate tool that provides the description and identification of the land as well as continous recording (continuous recording rather than land rights). ${ }^{[24]}$ In Article 19 of the Agrarian Act it is stated that all land rights must be registered, of course, with the assumption including ulayat land (Article 3 Agrarian Act), but in Article 9 of Government Regulation number 24 of 1997, no ulayat land is seen as the object of land registration. This shows that ulayat land is not a land object that must be guaranteed legal certainty

If communal land is not included in the land registration object, will communal land be registered? Which legal basis will be used? Is it assumed that the ulayat right is the same or equivalent of State land or indivual land, while its existence is expressly regulated in a separate Article in the Agrarian Act. The concept of communal land in Agrarian Act that does not develop in organic rules, then today often lead to conflict. The emergence of the provisions on the Village and to provide legal certainty quiet assets in the form of land becomes become blurred. In other words, nagari's land assets are ulayat increasingly leading to legal uncertainty, if the legal certainty is only proven by the certificate of land rights.

The reality in West Sumatra, Nagari Parahiyangan is awarded as one of the best villages in the world, but its nagari land assets are not registered. Likewise, Kapau Nagari, even with its own uniqueness, no one one citizen allowed to certifying their land in the National Land Agency, but it recorded in its nagari's asset. in Nagari Tarantang and Nagari Harau, formerly a Nagari because it is located in the area of Lima Puluh Kota then the certificate is still on behalf of the Regional Government of Lima Puluh City, while Nagari Harau has not been certified yet. Besides the asset of Village in Batang Kabung Ganting Village, Padang City even though already in the city area but still not certified.

Concerning the asset nagari in Nagari Parahiyangan, Nagari Kapau, and Nagari Harau, declared nagari asset in the form of land is communal land, but none of them are certified. However, in the report of the nagari asset, it is shown that the land is used for the wali nagari's office. In this case, although the legal certainty of asset in the form of certificate is not owned, but there is no legal certainty concerning the nagari asset, because the certainty is based on the sincere and voluntary submission of the owner of the customary right, as long as it is used for nagari governance.

Based on West Sumatera Regional Regulation Number 2 of 2007, nagari is a legal entity, which is integral with the government of Indonesia, the land assets are managed similarly to the management of the land asset of the City Government, the Regency Government, the Provincial Government.

In the Village Act it was suggested that one of the origin of the village/Nagari land asset is communal land. It is seen that the Village Act is also carelessly incorporating village assets with communal lands. Concerning the Nagari asset in West Sumatra does not need a certification of communal land asset, but still guarantees Nagari governance regarding its uncertified assets.

Implementation of the communal land certification of Nagari's assets in the provision of legal certainty. Although the concept of land registration of Nagari's assets derived from communal land, its registration. In West Sumatra Regional Regulation Number 6 of 2008, the registration of communal land is carried out under Government Regulation Number 24 of 1997, which does not mention ulayat land as the object of land registration.

As a result of West Sumatera Regional Regulation of the Ulayat Right of West Sumatra which impose the customary rights of the village is registered with Government Regulation Number 24 of1997, so that it can be granted with the concept of communal right in Article 3 of Agrarian Act. 


\section{Conclusions}

Registration is an appropriate tool that provides the description and identification of the land as well as continous recording (continuous recording rather than land rights). ${ }^{[24]}$ In Article 19 of the Agrarian Act it is stated that all land rights must be registered, of course, with the assumption including ulayat land (Article 3 Agrarian Act), but in Article 9 of Government Regulation number 24 of 1997, no ulayat land is seen as the object of land registration. This shows that ulayat land is not a land object that must be guaranteed legal certainty

The concept of communal land in Agrarian Act that does not develop in organic rules, then today often lead to conflict. The emergence of the provisions on the Village and to provide legal certainty quiet assets in the form of land becomes become blurred. In other words, nagari's land assets are ulayat increasingly leading to legal uncertainty, if the legal certainty is only proven by the certificate of land rights.

In the land certificate of regional government assets derived from communal land, tribes and nagari through land procurement such as do not encounter significant obstacles, but juridically contradict with the concept of value and norm of Communal Right which recognized by Agrarian Act. Juridically, the legal certainty concerning Nagari's assets in the form of communal land must be registered with the provision of land registration (Government Regulation Number 24 of 1997) and proven by the certificate of land rights. But nagari's assets derived from ulayat land can not be registered or certified.

\section{References}

1. Y. Mirwati, Makalah dalam Pendaftaran Tanah Aset Pemerintah di Kabupaten Solok, p. 10(Sumbar, Koto Baru Solok 2016a)

2. Article 4 Paragraph (6) IndonesianRegulation of the Minister of Home Affairs Number 1 Year 2016

3. Article 4 paragraph (1) Indonesian Act Number 5 of 1960 concerning Basic Regulation on agrarian principles

4. Article 16 paragraph (1) Indonesian Act Number 5 of 1960 concerning Basic Regulation on agrarian principles

5. B. Harsono, Hukum Agraria Indonesia-Sejarah Pembentukan UUPA, p.265(Djabatan, Jakarta, 1999a)

6. Article 4 Paragraph (5) IndonesianRegulation of the Minister of Home Affairs Number 1 Year 2016

7. Article 4 Paragraph (3) IndonesianRegulation of the Minister of Home Affairs Number 1 Year 2016

8. H. Sutrisnio, Metodelogi Research jilid 1,p. 70(Andi Offset, Yogyakarta,1989a)

9. Suratman, Metode Penelitian Hukum, p. 52 (Alfabeta, Bandung, 2012)

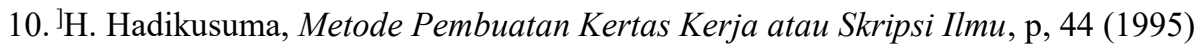

11. H. Sutrisnio, Metodelogi Research jilid 1,p. 70(Andi Offset, Yogyakarta,1989b)

12. H. Sutrisnio, Metodelogi Research jilid 1,p. 40(Andi Offset, Yogyakarta,1989c)

13. S Rahardjo, Ilmu Hukum, p. 20 (Citra Aditya Bakti, Bandung 1991a)

14. S Rahardjo, Ilmu Hukum, p. 20 (Citra Aditya Bakti, Bandung 1991b) 
15. B. Effendi, Pendaftaran Tanah di Indonesia, p.14(Raja Wali, Jakarta, 1993)

16. A.P. Parlindungan, Pendaftaran Tanah Di Indonesia. P.18 (Mandar Maju, Bandung, 1999a)

17. B. Harsono, Hukum Agraria Indonesia-Sejarah Pembentukan UUPA, p.155(Djambatan, Jakarta,1999b)

18. Y. Mirwati, Makalah dalam Pendaftaran Tanah Aset Pemerintah di Kabupaten Solok, p. 10(Sumbar, Koto Baru Solok 2016b)

19. M.Yusuf,Delapan langkah Pengelolaan Aset Daerah Menuju Pengelolaan Keuangan Daerah Terbaik, p. 11(Salemba Empat, Jakarta, 2010)

20. C. Soleh, \& H. Rochmansjah,Pengelolaan Keuangan dan Aset Daerah; Sebuah Pendekatan Struktural Menuju Tata Kelola Pemerintahan Yang Baik,Cetakan Edisi Kedua. p. 167(Fokusmedia, Bandung, 2010a)

21. ${ }^{\mathrm{C}}$. Soleh, \& H. Rochmansjah,Pengelolaan Keuangan dan Aset Daerah; Sebuah Pendekatan Struktural Menuju Tata Kelola Pemerintahan Yang Baik,Cetakan Edisi Kedua. p. 167(Fokusmedia, Bandung, 2010b)

22. M.Yusuf,Delapan langkah Pengelolaan Aset Daerah Menuju Pengelolaan Keuangan Daerah Terbaik, p. 11(Salemba Empat, Jakarta, 2010b)

23. C. Soleh, \& H. Rochmansjah,Pengelolaan Keuangan dan Aset Daerah; Sebuah Pendekatan Struktural Menuju Tata Kelola Pemerintahan Yang Baik, Cetakan Edisi Kedua. p. 167(Fokusmedia, Bandung, 2010c)

24. A.P. Parlindungan, Pendaftaran Tanah Di Indonesia. P.18 (Mandar Maju, Bandung, 1999b)

25. A.P. Parlindungan, Pendaftaran Tanah Di Indonesia. P.18 (Mandar Maju, Bandung, 1999b) 